\title{
Cold War Sewing Machines: Production and Consumption in 1950s China and Japan
}

\section{ANTONIA FINNANE}

With the "consumption turn" in the humanities and the social sciences, a phenomenon evident in English-language scholarship from the 1980s onward, production ceased to command the attention it had once received from historians. A recent (2012) study of the sewing machine in modern Japan by Harvard historian Andrew Gordon demonstrates the effects: what could feasibly have been published under the title "Making Machinists" was instead marketed as "Fabricating Consumers." What does it mean to talk about consumers in 1950s Japan, a time and place of hard work, thrift, and restraint? For Gordon an important premise was the role of women in the postwar economy. This provides a point of departure from which to explore the ideologies and practices of production and consumption across the Cold War dividing line between "consumerist" and "productionist" regimes in East Asia. The Cold War was a time of sharp differences between the two societies, but also a time of shared preoccupations with productivity and national growth. In their different political contexts, Japanese and Chinese women were acting out many of the same roles.

$\mathrm{D}$ URING THE COLD WAR, it was common for societies on either side of the great divide to be described in dichotomous terms set by the rivalry between capitalism and socialism. Since its end, historians have been attending to what these societies had in common with each other, or where they dovetailed (Booker and Juraga 2002; Vowinckel, Payk, and Lindenberger 2012). In East Asia, this revisionism is apparent in treatments of the PRC and ROC (mainland China and Taiwan), states governed by single-party authoritarian regimes with a strong shared history (Kirby 2004; G. T. Wang 2006, 121-54; cf. Wu 1994). Terrain shared by Mao's China and the Liberal Democratic Party's Japan has less often been identified, or has even been patently ignored (Shiraishi and Hau 2010, 32). The two countries were by definition on different sides of an experiment that featured "the productionism of the Soviet and Chinese models" on one side of the divide and "the consumerism of the West," specifically the "US, Europe, and Japan," on the other (Marks 2007, 176). Although Japan is often treated as a special case among capitalist liberal democracies, and in post-Cold War contexts as an East Asian rather than a Western economy, there are certainly grounds for thinking about it in association with the United States for the peri-bellum decades (Iriye 1992, 110). The two countries were first rivals in the Pacific and then allies, the one pursuing the other's economic

Antonia Finnane (a.finnane@unimelb.edu.au) is Professor in the School of Historical and Philosophical Studies at the University of Melbourne. 
achievements to a point where, by the end of the Cold War, it was close to matching them.

These historical parallels and connections may have been among the factors underpinning the methodology adopted by Andrew Gordon in Fabricating Consumers: The Sewing Machine in Modern Japan (2012), an engaging study of the manufacture and use of the domestic sewing machine in Japan written in light of the American experience. The United States is not the only other country Gordon mentions. Britain and Germany, countries on the same side of the Cold War and like the United States historically prominent as sites of sewing machine production and use, also make an appearance in the book. But nearby China, which was to succeed Japan as the world's largest manufacturer of sewing machines, is largely overlooked. One of the reasons for this discrimination must lie in the "consumers" of the book's title, graphically depicted in images of happy Japanese housewives with sewing machines that resonate with advertisements in 1950s American magazines. The gendered citizen consumer, encapsulated in the figure of the housewife and well documented by Gordon for Japan, has become a stock character in studies of Cold War culture (Pence 2006; Reid 2011, 133), representing the free market economies in much the same way as the girl on a tractor was used to symbolize the command economies on the other side of the Cold War trenches. Even taking into account Karl Gerth's (2013) careful excavation of consumer-oriented advertisements in the early PRC, it would seem difficult to find much in China that would render it comparable to Japan in the realm of commercial culture in the third quarter of the twentieth century.

Yet the story Gordon tells is about production as well as consumption, and here there was indeed common ground between Japan and China. The starting points for postwar development of the sewing machine industry in the two countries were very different, but the rates of growth in the third quarter of the twentieth century were almost equally impressive. In Japan, 134,000 machines were manufactured in 1947, 166,000 in 1948, and more than a million by 1951. In 1969, output "peaked at 4.3 million" (Gordon 2012, 153-54). China went from a total of 4,500 machines in 1949 to 3,567,000 in 1975 ("Dangdai Zhongguo" Congshu Bianjibu 1985-86, 328-29). As might be expected, Chinese production expanded rapidly in the Reform Era, doubling from 4,860,000 to 9,350,000 units between 1978 and 1984 (Guojia Tongju 1985, 110, 153-55), but the base line established by the beginning of the Reform Era was already quite high. Martin King Whyte found not much difference in domestic distribution between 1975 and 1980, indicating that the initial turnaround was an effect of economic reform in first half of the seventies: it began in Mao's China, not Deng's. By the beginning of the Reform Era in 1980, there was already a sewing machine in two out of every three households in forty-four Chinese cities sampled by the State Statistical Bureau (Whyte $1985,93)$.

In the 1950s, different meanings were associated with the proliferation of machines in the two countries. A typical Japanese testimonial for the benefits of using the mishin unfolds as follows: Kawaguchi Kinuko worked in a dress-shop before the war and now wants to try home-based work. Her husband, a factory worker, objects, but has a change of heart when he sees how much she earns from making blouses for her neighbors. He brings home orders from his workmates for shirts. She develops her fashion skills by reading, and sets her sights on opening a shop: "Her husband is so impressed 
he has started to come home early to help out with the housework." The thread of the story winds its way through the intricacies of domestic life: the husband's initial opposition and eventual conversion to the wife's leverage of her sewing skills for commercial advantage are central points in the narrative. She not only makes money: she also effects a progressive transformation in husband-wife relations. She does so without actually leaving the home, but the latter possibility seems to be on the horizon (Gordon 2012, 176).

A Chinese counterpart to Kinuko can be found in the figure of Zhang Cuihua 张翠华, heroine of a play called The Sewing Machine that was staged in 1958, at the beginning of the Great Leap Forward. The play opens at daybreak with Cuihua at her machine, putting the finishing touches to a pair of trousers. She has been up sewing all night, too excited to sleep after having attended a meeting about the "three big changes" of the day: collectivization of production, collectivization of daily life, and collective child care. Her mother-in-law, who shortly appears on stage with baby in arms, is opposed to all these changes. She rightly senses their implications: the sewing machine will be turned over to a collective production unit, and her grandson will end up in a childcare center. Seeking to rein in her daughter-in-law's revolutionary enthusiasm, she surreptitiously sends the sewing machine off to a dealer, telling Cuihua that she has given it to her daughter. A distressed Cuihua is quickly consoled when her husband arrives home and approves his wife's down-payment on another sewing machine. Lo and behold, the second-hand machine that she subsequently purchases from the dealer turns out to be her own! The mother-in-law, exposed and embarrassed, capitulates, and sees the light: sending the child to crèche seems after all a very good idea, and likewise committing the sewing machine to the collective. As it happens, the collective has nowhere to set up its sewing business, and hapless mother-in-law has also to agree, cheerfully, to her home being used as a factory during the day (Xiong 1958).

The two stories could readily be assigned to separate categories of Cold War ideology: the Japanese testimonial features an emphasis on family solidarity and cooperation, individual initiative, and the economic advantage of the family unit, while the Chinese propaganda play extols extra-familial social ties, "the collective," a rejection of the work-for-profit ethic (especially profit for the individual or family), and cooperation for the greater social good. Yet the overlap is considerable. First, the narratives share a basic premise: women on both sides of the East China Sea engaged in home-based production of clothing, whether hand-sewn or machine-made. Second, the wage-earning, productive capacity of the machine-sewing wife-mother figure is recognized. Whether in socialist China or in capitalist Japan, the author takes for granted that the reader will understand the equivalence between clothes manufacture by women and household income. Third, the gender structure of the family as economic unit is the same. The dialogue between husband and wife in the two instances differs, but the narrative in each case depends on the husband's support of the wife's initiative. Both socialist and capitalist logic lead to the identification of the wife/mother figure as producer and to a progressive relationship between husband and wife as crucial to social and economic progress.

The overlap in themes and significations in these two stories demonstrates in small the inadequacy of simple Cold War categorizations of consumerism and productionism to account for social and economic change in Japan and China in the third quarter of the twentieth century. In Japan, economic growth based on commodity production was 
attended by a "profound ambivalence" towards consumption (Garon and McLachlan 2006 , 4). Postwar society in Japan was marked by a certain nihilism, a sense "of the collapse of the social order externally and of spiritual decay internally," in the words of Keiji Nishitani (1990, 3-4). To nihilism was conjoined on the one hand a commitment to growth and the production of prosperity (O'Bryan 2009), and on the other searches for meaning in community and the family. Consumption, defined as the purchase of household goods, rose in the 1950s, but then so did savings (Partner 1999, 184). The Housewives Association was urged to look beyond and indeed away from consumption to life goals that were spiritual rather than material (Garon 1998, 186). Women's groups on right and left reacted against the industrial machine, openly attacking the cult of productivity (seisansei shijōshugi 生産性至上主義) (Uno 1993, 313).

Were sewing machines principally items of consumption or more importantly tools for production on the part of Japanese women? Gordon's analysis suggests the former, but Ronald Dore, in a famous fieldwork study conducted in the 1950s, found that the sewing machine was little used for leisure activity, and appears not to have been regarded as a luxury item (unlike an ice-box, for instance, or an electric fan): rather, it was "primarily a means of economizing on clothing expenditure" (Dore 1958, 85). The conclusion to be drawn is that women were spending all those hours at the machine because they were making clothes for the family, or for the market, or both. Gordon documents exactly this while stressing an apparent teleological endpoint of the process: leisure use or even mere possession of the machine. There was, he finds, a gradual move "away from the sewing machine as an economizing tool of the wage-earning, producing wife and towards the mishin as the indispensable tool of the happy bride and an instrument allowing a female consumer to fabricate a fashionable, good life" (Gordon 2012, 176). In the balance of this analysis can be sensed the weight of historical tendencies to view the housewife as a (non-producing) consumer, spending the money earned by her working husband. In nineteenth-century France, as Judith Coffin (1996) has pointed out, the sociology of consumption linked leisure and consumption, assigned them to the home, and declared women the major performers in what were essentially passive roles in the economy. This is consistent with a view of "sewing machines for home-use [as] durable consumer goods, while industrial sewing machines are capital goods," to quote Hirohisa Kohama $(2007,205)$. Yet as long as domestic sewing machines were being used to make money, or even simply to save money, the line between the two categories must be blurred. Under both circumstances, the categorization of the Japanese housewife as the definitive consumer seems problematic. Looked at from a perspective supplied by J. K. Galbraith, to the extent that a consumer economy was developing in Japan in the 1950 s, the most significant role played by women in its development was surely a service role (Galbraith 1974, 33; cf. Horioka 1993; Tachi 1966, 24).

Compared to China in this period, or to the Soviet Union, Japan did of course look like a consumer's paradise. The terms "consumers" and "consumption," suggestive of market mechanisms, had a place in socialist regimes. China had consumer cooperatives, organizations with a hoary revolutionary heritage and manifestations in both Nationalist and Communist China (Fitzgerald 1997; Perry 2012). In the People’s Republic, these cooperatives were meant to facilitate access to necessities of daily life: fuel, rice, oil, salt, vegetables, soap, towels, toothbrush, toothpaste, matches, cigarettes, and medicines. It can be seen from this list, taken from a report on the workers' consumer co-op at the 
Shanghai No. 9 Cotton Textiles Factory (SMA 1963), that consumption (xiaofei) need not mean luxury consumption but simply what was acquired through purchase. Yet the term had a reserve of negative associations. In 1958, the country as a whole was being urged to take a turn that would "turn consumers into producers, and turn consumer towns into producing towns” (Yue and Xu 1958). Within this framework, plainly, being a producer was much more important than being a consumer.

In this context, was a domestic sewing machine to be considered a consumer or a "capital" (i.e., a productive) item? Was it a luxury good, to be purchased by families as a sign of the prosperity achievable under socialism, or was it a component in the industrialization drive that was aiming to replace manual work in China with machines? As might be expected, the emphasis in the industry was very much on production, but just as a strong productivity ethic remained visible in Japan even while economic growth, advertising, and fashion lent weight to the impression of a burgeoning consumerism, so too in China, a history of advertising, fashion, and brand competition evident in the early development of the sewing machine industry left its mark on the industry as it took off in the decidedly productionist 1950s.

It is worth noting that these were more than simply parallel developments: merely to plot the trajectories of the two national industries side by side would be to obscure their shared terrain. In the opening pages of his book, Gordon notes the historical role played by China in Japanese cultural and economic change, before the advent of the Black Ships. Although it then quickly disappears from the book, China did not of course disappear from the Japanese horizon. In the decades when Singer was expanding into East Asia, a greater Japanese empire was taking shape. The quiet activities of Japanese women plying their needles and the manufacture and retail of Japanese sewing machines and their parts were alike involved with the making and maintenance of this empire. In 1937, women on the streets of cities in Japan were to be seen sewing senninbari, a thousand stitches for each white belt to protect the soldier going to the front-in this case the China front (Igarashi 2000, 239). In Manchukuo in 1945, fully given over to the Japanese war effort, students "day after day ... had only meager meals and worked at sewing machines” (Gibney 2007, 110). After the war, to paraphrase John Dower (1998, 67), swords were turned into plowshares, and sewing machines were produced by factories that had been constructed to make machine guns. The sewing machines, like the guns, were destined for China. In 1947, Shanghai accounted for nearly the entire export of Japanese sewing machines. The following year, Japanese manufacturers were complaining that "exports to China, our greatest consumer, are being hampered by the unsettled [political] conditions..." (Oriental Economist 1949, 63). Despite the "unsettled" conditions, exports continued after the Communist victory, with sewing machines listed among approved imports in Sino-Japanese Trade Agreements of the 1950s (People's China 1953), and reported to be in high demand (Pakenham 1953). After a freeze in relations in the late fifties, contact between the two countries resumed, and by 1965 Japan was China's top trading partner.

Japan is famously Janus-faced: if one face is turned towards the United States, or the West more broadly, the other is turned towards Asia, and particularly China. This other "Other" is a silent one in Gordon's account, its story waiting to be told. The role of Singer in the global history of sewing machines makes the United States a natural point of reference in any local history of this industry. Considered from an East Asian regional 
perspective, however, a different interpretation and a slightly different story of sewing machines seem possible.

In Japan, the sewing machine is called a mishin ミシン. In China the term is translated literally as fengrenji (sewing machine), but a variety of other words are or have been used, with variations across space and time. Dung Kai-cheung $(2005,123)$ comments on exactly this fact from the perspective of a Cantonese speaker:

I don't know why "clothing vehicles" (yiche 衣车, or in Cantonese jice) are generally Singer products. "Clothing vehicles" are properly termed "sewing machines," but in our dialect they are called "garment vehicles." Apart from the fact they have wheels to move [the cloth] forward, this might be because early machines were driven by a pedal.... When Chinese first encountered the sewing machine, they called it an iron tailor (tiecaifeng 铁裁㖓).

As this passage indicates, the term Singer, in Chinese Shengjia, has a high level of recognition in China and, as in the West, is a byword for sewing machine. "Clothing vehicle," or corresponding forms depending on dialect area, is widely used in south China. In Shanghai and its hinterland, the colloquial term is or was "Western machine" (yangji 洋机) (Cheng and He 2005, 86; Qian 2003, 153). "Iron tailor," as Dung states, was in use very early in the documented history of the sewing machine in China. A young Zhang Deyi (1847-1918) had his first glimpse of a sewing machine in 1866, when he was visiting the home of General Charles Gordon, and described it as an "iron tailor" (Cheng and He 2005, 86).

In Japan, it is widely believed that the first sewing machine was introduced by a young man who brought one back for his mother in 1859 (Gordon 2012, 14). In China, such a deliciously Mencian moment has yet to be established. The nearest approximation is the story of late Qing high official Li Hongzhang visiting the Singer factory in Glasgow in 1896 and taking a machine back to present to the Empress Dowager (Finnane 2008, 116). By this time, as Zang Deyi’s memoir shows, sewing machines had a history of at least thirty years in China. Standard accounts vary in their claims of first arrival, from industrial machines introduced in the 1870s by Mustard and Co. (otherwise associated with the tobacco trade) (Shanghai difangzhi 2011) to a New Home domestic machine imported in 1890 ("Dangdai Zhongguo" Congshu Bianjibu 1985-86, 225). ${ }^{1}$ But these are rather late dates. In Canton and Hong Kong there must already have been a number of sewing machines in the 1860s, for according to Gordon (2012, 17-18) it was tailors from these parts who introduced them to Japan. The first machines were probably brought to China by foreigners such as General Gordon, or else sent to them from abroad: hence the Wheeler and Wilson machine sent to the Protestant Episcopal Mission of Shanghai in 1867 (Hale and Godey 1867, 374), and a Grover and Baker brought to Beijing in 1869 (Bonney 1875, 2:514).

As in Japan, take-up of the technology was steady but slow. Gordon $(2012,186)$ argues for a close relationship between Western attire and the use of the sewing

${ }^{1}$ In China, the New Home brand was known as Old Dog (laogou 老狗) due to the image on the logo, which was of a dog. 
machine. Early advocates of the sewing machine in China agreed: from the simple premise that "the men of China will never become Christians till they wear shirts," it followed that the sewing machine was absolutely essential to China because "such a multitude of men" could never be appropriately clothed without it (Hale and Godey 1867, 374). The relationship between the dress-style and the use of the machine appears to have been syntagmatic, with the adoption of Western dress strongly indicating adoption of the equally Western sewing machine. In 1912-13, the first two years of the Republic, a fad for Western clothing was to be observed in Chinese cities, and there was simultaneously "a marked increase in imports of sewing machines to China” (J. H. Arnold 1919, 511).

Again as in Japan, Singer emerged as the dominant supplier of sewing machines in China in the early decades of the twentieth century. Its global ambitions were evident at the 1893 Chicago World's Fair, when it distributed postcards of Singer sewing machines in various international contexts, including China (see figure 1). An early rival, in Southeast Asia as well as in China (Khoo 2006, 95), was the German company Gritzner (later taken over by Pfaff). Gritzner manufactured sock-making as well as sewing machines, ${ }^{2}$ ran sewing schools, and advertised its wares aggressively in the Chinese press in the years leading up to World War I (Tan 2004). A growing number of machines in Shanghai and Guangzhou gave rise to side industries in workshops that could manufacture small parts and supply repair services. From these evolved the early local sewing machine manufacturers, such as the short-lived Shengmei 胜美, founded in 1928; Ruan Yaoji 阮耀基 Sewing Machine Co., opened in 1936 on premises originally used for making sockknitting machines; Xiechang 协昌 (Yah Chong); and-in Guangzhou-Huanan 华南 ("Dangdai Zhongguo" Congshu Bianjibu 1985-86, 225; Shanghai difangzhi 2011). Singer competed successfully with these local entrepreneurs: in Chinese accounts it stands accused of dumping, among other tactics, to block their penetration of its market (Huanan 1959, 3). In China, as elsewhere, it advertised itself as affordable through sale on payment plans, and it sold a variety of machines: sock-making, leatherworking, portable, and fold-away styles (see figure 2). It retained an office on Nanjing Road, Shanghai, until at least 1954, along with a sewing school on Huaihai Middle Road (formerly Avenue Joffre) (SMA 1954).

In China the early machine makers typically produced the shell of the machine and sourced the parts elsewhere, so that production took place through a network of small manufacturers and suppliers. Overall, there was a lack of standardization and precision, and production was slow. In all China, from around 198 businesses, large and small, less than five thousand machines were produced in 1949 ("Dangdai Zhongguo" Congshu Bianjibu 1985-86, 228). This low baseline meant that despite impressive rates of growth in the 1950s, the total number of machines per head of population was still relatively small by the end of the decade. Sewing machines are highly durable: most of those produced at any time in the twentieth century were probably still operative in the 1950s. To machines made in China must be added foreign brands, including Japanese brands, imported prior to 1949 , or even in the 1950s. The total machine stock also included an unknown number from the Soviet Union and Eastern Europe. Brands appearing on

\footnotetext{
${ }^{2}$ See Finnane (2008, 121 fig. 5.13). I speculated in this book that the 'G' sock-knitting machines widely advertised in early Republican China were made by a British hosier, but they were almost certainly Gritzner machines.
} 


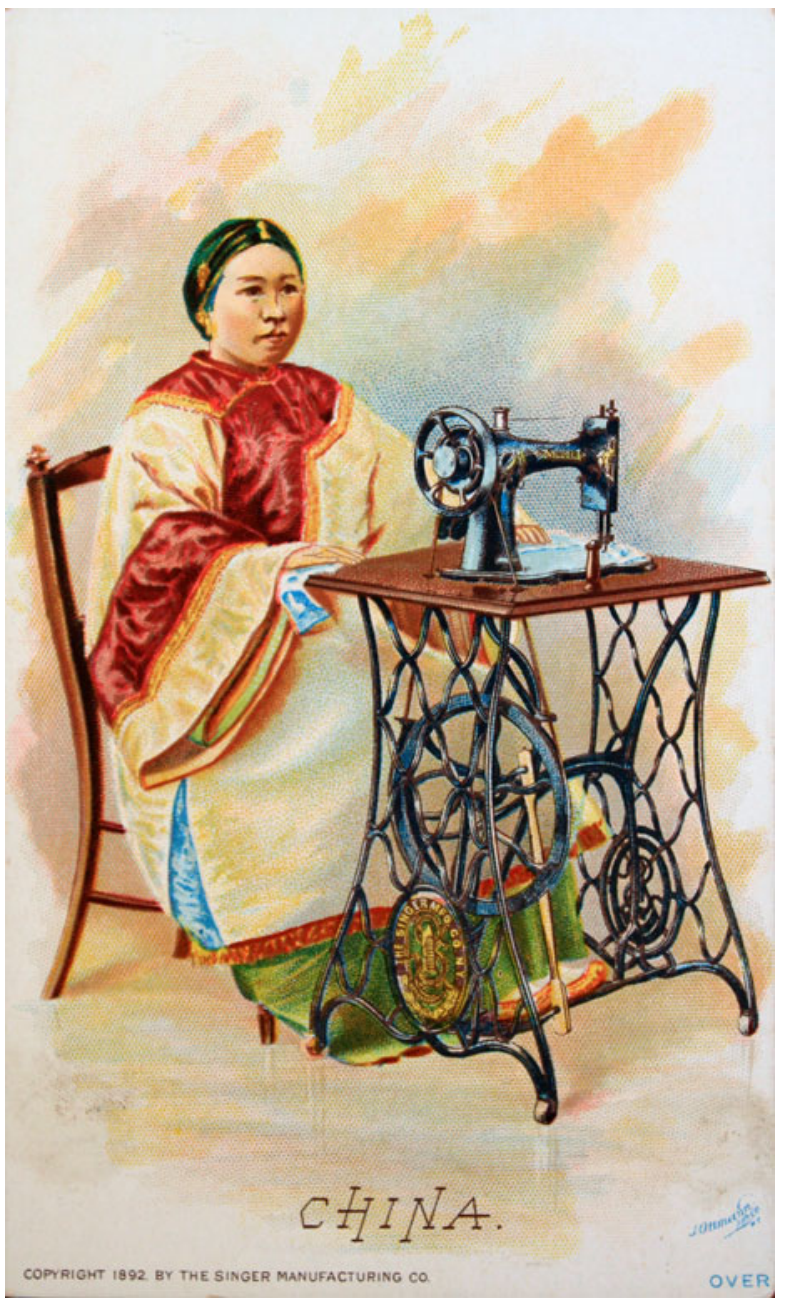

Figure 1. Singer advertising card, "China," Chicago World's Fair, 1893. Author's collection.

Chinese collectors' sites now include Kohler (East Germany); Gritzner R (vibrating shuttle style, for family use); and Csepel, supposed by a collector to be of Soviet origin but actually Hungarian (Bodnár 2001, 88; He 2013). Nationwide, there can have been only a few million machines in operation by the beginning of the Great Leap Forward. In Japan, household ownership of sewing machines stood at 75 percent in the middle of the 1950s (Gordon 2012, 154). In Beijing, by contrast, there were sewing machines in 4 percent of urban households and 3 percent of rural households in 1955. Many of these may have been in home-based dressmaking or tailoring businesses. But numbers rose steadily over the next decade and reportedly stood at nearly 30 percent of urban households in the Beijing municipality and close to 20 percent of rural households on the eve of the Cultural Revolution (Zhu and Zhang 2005, 33, 36).

Despite the differences in scale, the circumstances of production and use did not vary as sharply as might be imagined. First, as in Japan so too in China-sewing 


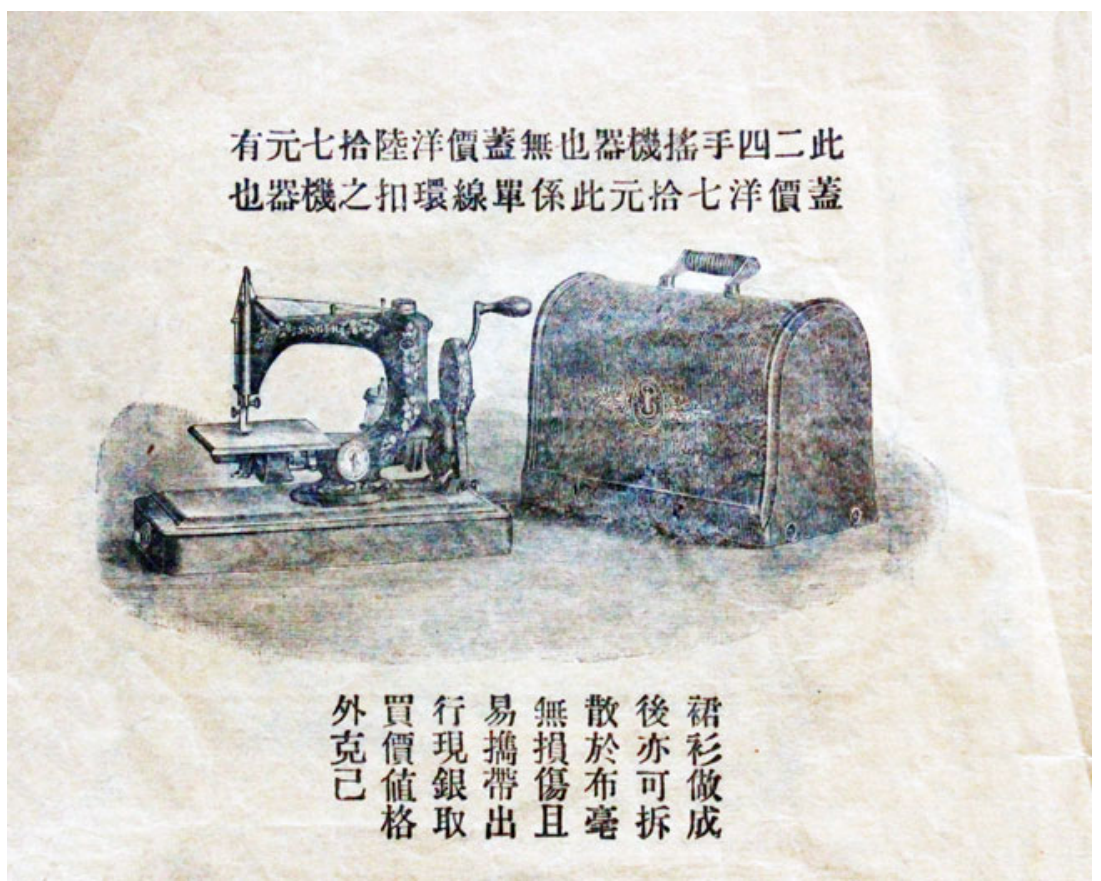

Figure 2. Catalog listing of a portable Singer 24 sewing machine with optional cover. The cost was $\$ 67.00$, or $\$ 70.00$ with cover included (Shengia, n.d.).

schools sprang up in the 1950s. How many, and how long they lasted, is difficult to say, but in 1952 in Beijing there were twenty large-scale vocational schools, run under the auspices of the Culture and Education Bureau. Hundreds of graduates emerged each month from these institutions, with an estimated 20 to 30 percent skilled enough to go into business (Finnane 2011). In Tianjin, the Minde Part-time Vocational School, founded on March 8 (Women's Day) in 1949, had produced 700 graduates by 1952 (Sun 1951). In places like Tianjin, Shanghai, and Beijing, there were an unknown number of private sewing schools, teaching materials for which went through multiple editions (e.g., Fu 1954; Tang 1953; Wang Guizhang 1950). The schools provided women, and some men, with skills in production that they could turn to use in an economic environment that was not favorable to some older professions and lines of trade.

These schools were serviceable, too, in drawing women out of the home and into the workforce, turning them from consumers and "parasites" into contributors to society and the economy. This aim, unambiguously articulated during the New Democracy period, would seem to indicate a sociopolitical environment in China antipathetic to the production of anything like the "professional housewife" that emerged in Japan. In practice, the shifting parameters of state discourse on women in socialist society allowed a socialist variant of the housewife category. At critical junctures in the cycle of economic planning between 1949 and 1964, as Song Shaopeng has shown, housework was valorized as productive. The "five goods" campaign of 1956 set goals of service and self-improvement for women that were consistent with the ethos of Japanese housewifery: "maintain good harmony in the family and give mutual assistance, organize a good domestic life, give 
children a good education, encourage their dear ones to do good work and study well, and push themselves to obtain good results in their studies" (Song 2007, 53).

“Organizing a good domestic life" (jiating shenghuo anpai hao 家庭生活安排好) meant the provision of clothing, among other things. Gordon (2012) pays particular attention to the place of sewing in Japanese life, the prominence of which he explains by reference to both tradition (notably the tradition of female handicrafts) and modernity (the popularization of Western dress in the postwar era). The former predisposed Japanese women to spend hours at home sewing, while the latter predisposed them to use machines for the purpose, Western fashions being more efficiently produced by the sewing machine than by hand. That there were parallels with China hardly needs stating. The classic "women's work” (nügong 女工, nühong 女红) of China was needlework, a practice widely observed and described by commentators on Chinese society over the centuries. Skills in needlework were what women besought of the Weaving Maid on the Double Seventh festival (Buckhardt 2013, 32-33), and what they sought to display to their future in-laws prior to their marriage. In the early nineteenth century, Karl Gutzlaff found Chinese women almost always to be "sewing, weaving, embroidering..." (Gutzlaff 1838, 1:508). In the early twentieth century, the new schools set up for girls by the late Qing reformers included instruction in needlework at both the elementary and teaching training levels (Zheng 2001, 201). If a woman was from a moneyed family, she used her needle for embroidery. If she was poor, she used it to sew clothes. Gail Hershatter has evocatively recounted the experience of sewing as recalled by rural women in 1950s Shaanxi: sewing was their constant companion-they took it out to the fields, to meetings, to bed, even to the toilet (Hershatter 2011, 191-92). Across the Taiwan Strait, the state-sponsored “women's movement” was “synonymous with ‘women's work, such as sewing uniforms for soldiers" (Tsui 1993, 210).

At first glance, the products of sewing in 1950s China look very different from what was coming off the sewing machines of Japanese housewives, but the technical shift from untailored to tailored garments in the two countries was comparable. In rural China, there was indeed not much change in everyday wear: as had apparently always been the case, pants were cut the same back and front while jackets had no shoulder seams. Cutting was simple and sewing minimized. For townspeople, however, there were major changes, not all at once but gradually, from the long gown and qipao to various sorts of trousers, jackets, shirts, ties, blouses, and skirts. Western and socialist styles flourished side by side for a while before the socialist won out: Sun Yat-sen suit, Lenin coat, Youth coat, Cadre suit, People’s suit (also known as “construction suit”-jianshezhuang 建设装), Michurin shirt, and Russian-style frock (bulaji 布拉吉). These garments were regarded by outsiders, and generally by the Chinese themselves, as distinctively Chinese with some Russian inflections. It can easily be overlooked that, like standard Western clothes, they were essentially tailored garments that in Chinese eyes were generically Western. One "Western" tailoring guide put out in Beijing in 1951 contained only such garments ( $\mathrm{Fu} \mathrm{1951).} \mathrm{Pants} \mathrm{were}$ shaped, shoulders fitted, pockets inset or patched but anyway incorporated into the garment as features that defined it stylistically as Western.

Skills in the cutting, assembling, and machine-sewing of such garments were basic to the training offered in sewing schools, and bring us to the heart of the question of why sewing schools flourished in East Asia at a time of vestimentary transformation. The manuals produced by and for the schools show what was technically particular about the 
new vestimentary regime. In the correspondence course operated by King Fair Sewing School in Shanghai, the regular sewing class included an introduction to machine accessories, how to button-hole, and how to make different sorts of pockets. Button-holing, with its requirement for a concentrated double-row of stitches, was peculiar to Western dressmaking and was greatly facilitated by the use of a sewing machine. Pockets, too, were exogenous elements in the Chinese wardrobe. Patch pockets such as those characterized the Sun Yat-sen suit were technologically simple apart from shaping the flaps, but inset pockets such as those used for military uniforms and Youth coats (school uniforms) posed a challenge that was again more easily met with a sewing machine.

In the cutting class, students were introduced to the basic principles of cutting and making patterns, and received instructions for the creation of a basic clothing range for the New China: Lenin coat, Western suit coat, singlet (vest), Western suit trousers, qipao, short overcoat, children's clothing, and workers' clothing (dungarees). Cutting the cloth for these garments was a more precise and demanding task than cutting cloth for a long gown or Chinese-style jacket-much as these latter garments would be cut with great skill by a good tailor. Having grown up in homes where their clothes had been made by tailors, or where home-sewing had been of garments in the Chinese style, women of the New China can only in rare cases have imbibed knowledge of how to scale up patterns, take measurements, or use a treadle machine. In this respect, they were different from women in the West, who were likely to have been exposed to dress-making in the family home from childhood, but they were quite like their counterparts in Japan. Skill acquisition was surely a major factor in the proliferation of sewing schools in post-1949 China and their popularity in postwar Japan (cf. Gordon 2012, 223).

Among private operators of Chinese sewing schools in the early fifties, it is probable that a number had been trained in Japan. Lin Zhengbao 林正苍 was one. Founder of a sewing school called the Meilin Tailoring and Embroidering Training School (Meilin Caijian Fengxiu Xuexiao 梅林裁剪缝绣学校), Lin showed in his self-promotion the confused mix of status markers available to citizens of the PRC in the 1950s, before the anti-rightist movement. On the one hand, he used language and expressed sentiments appropriate to the circumstances of New China, addressing readers of his Guide to Tailoring as "dear comrades," and hailing the virtues of labor, production, and women's independence. On the other hand, he had no qualms about revealing his links with Japan, so recently at war with China. His diplomas from the Tokyo Western Clothing School_one for gentlemen's wear and one for women's and children's — were displayed in the opening section of the manual. He had graduated in 1942, in the middle of the war (Lin 1954). Clearly, any resentment of Japan arising from the war was at this stage balanced by the prestige of possessing Japanese know-how. Wang Guizhang 王圭璋, who ran the King Fair Sewing School, may have had equivalent training. Her graduating photo, published in the King Fair Sewing Guide, was taken in 1941 (Wang Guizhang 1950). Sun Po 孙颇, the head teacher at the Tianjin Minde school, trained in Yantai, which was dominated by Japanese interests since the Treaty of Versailles and fully occupied by Japan during the war (Sun 1951).

Regionally, Japan was a significant agent in technology transfer, its leadership role enhanced by its colonial powers. In a short story published in 1918, Korean artist and writer Na Hye-sŏk wrote of her eponymous heroine that she had learned to sew Western shirts through a machine-sewing school run by a Japanese woman. She made 
sketches from Japanese materials, and jotted down measurements, acting as a cultural broker for the transmission of modern sewing skills from Japan to Korea, and from

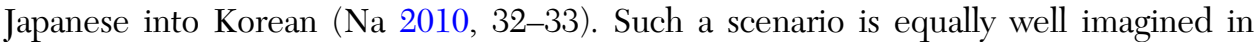
China (Ji and Chen 2003). Among the many Japanese publications remaining in China from the prewar years are copies of a sewing supplement to the May 1936 edition of Fujin kurabu - the "Ladies Club" magazine (Sechiyama 2013, 91-92). The author Sugino Yoshiko 杉野芳子 (1892-1978) was the founder in 1926 of the Dressmaking College for Women in Tokyo. She did not design the supplement for a Chinese readership, but the price of overseas postage provided on the inside cover shows that it was meant for overseas as well as domestic distribution. With a Janome sewing machine featured inside the front cover and the Dressmaking College for Women advertised inside the back, this magazine, even while delivering in a "teach yourself" mode, epitomized the cultural complex described by Gordon (2012) for a later date: sewing machines, Western dress, and sewing schools. Publications from the 1950s by the same author were also to be found in China (or at least can be found there now), as well as pattern books from Hong Kong and Southeast Asia. It would seem, in short, that some of the information about fashion and dressmaking that shaped attitudes in Japan and other parts of the former Japanese empire continued to trickle into China long after the construction of the bamboo curtain.

But for just how long? In a carefully documented discussion of advertising in the early decades of the PRC, Karl Gerth (2013) is at pains to point out the continuities in advertising (and more broadly consumer culture) from the Nationalist to the Communist era, and likewise the international context of advertising in the PRC. Advertising within the sewing machine industry and the textiles and apparel trades by and large bears out his observations for the early fifties. The King Fair Instructions for Sewing and Stitching, the first edition of which appeared in December 1949, offers an illustration. The manual opens with an advertisement for a sewing machine, in a style not too different from that illustrated by Gordon for Japan in the same period (see figure 3). The machine is Butterfly brand, known at the time as Invincible (the word for invincible, wudi 无敌, being a homonym for the word for butterfly in Shanghai dialect). The maker was Xiechang, known both locally and internationally as Yah Chong, the foremost manufacturer of machines in China at the time and probably the supplier of machines to this sewing school (one for each student). The young woman shown at the machine is dressed fashionably in Chinese style, with high heels, bare or stockinged legs, and a 1940s haircut. She is making a child's dress (see figure 3). Here surely is the figure of the housewife as machinist, entirely comparable to the Japanese model.

Published within a very short time of the fall of Shanghai to Communist forces, this manual shows all the signs of an industry in transition from the Nationalist to the Communist era. On the one hand, it was a product of private enterprise in a commercialized social context. Not only was the Butterfly sewing machine advertised; so too, in another full-page advertisement, were fabrics: Twin Cats Brand (Shuangmaopai 双猫牌) and Wee Lass Brand (Xiaonanpai 小图牌) serge_- “available from every woolen fabrics outlet.” The manual was also in itself an advertisement for the sewing school. Wang Guizhang’s photo, in graduation dress complete with mortar board, establishes her credentials as a teacher. Photos of students outside the school and inside the classroom suggest a proper 


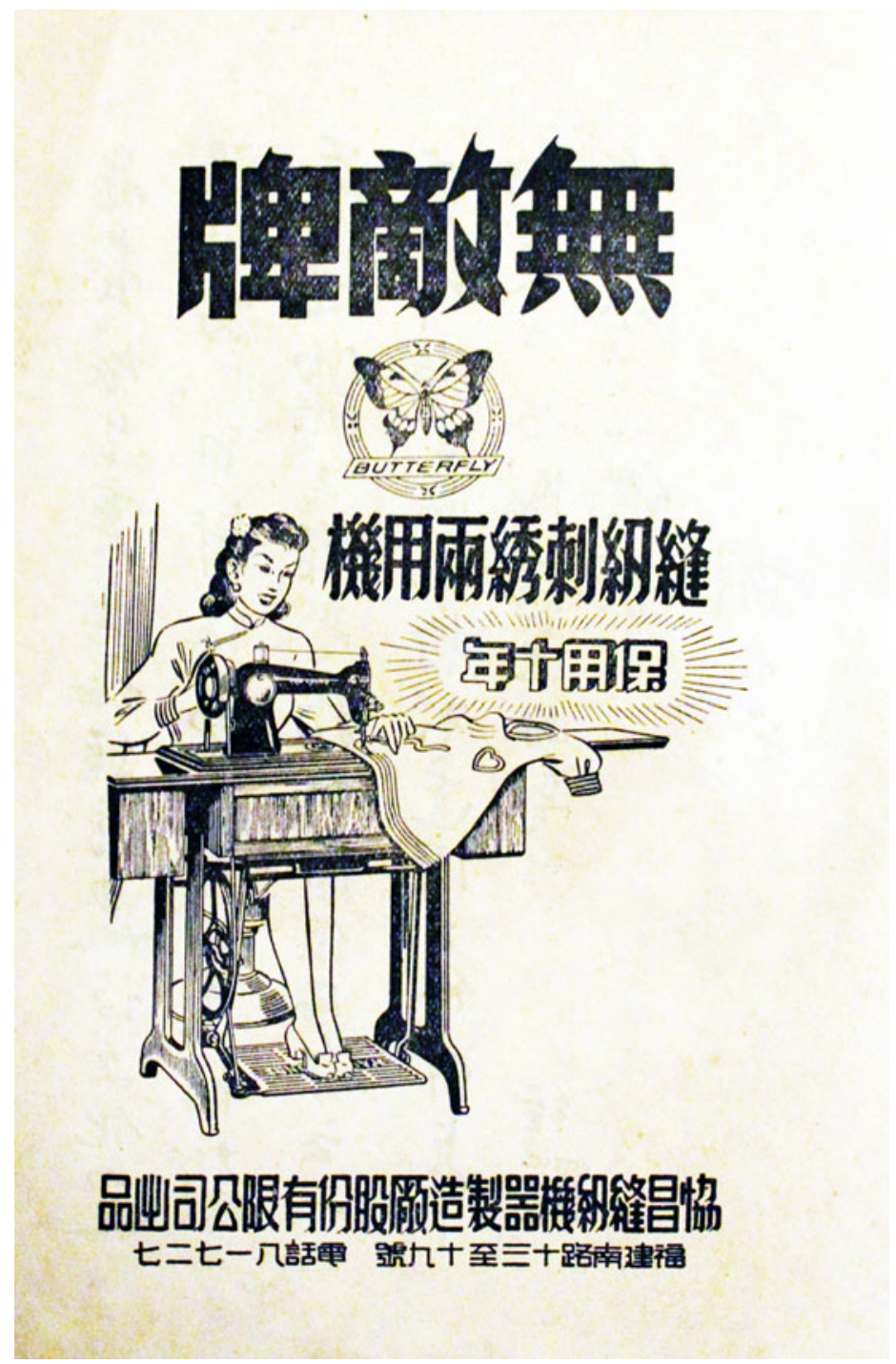

Figure 3. Advertisement for Yah Chong's Butterfly ("Invincible") sewing machine. A ten-year guarantee is offered on the machine, which is advertised as having both sewing and embroidery capacities (Wang Guizhang 1950).

environment for women to learn sewing. Technical specifications for the Yah Chong machine, set out within the manual, include a pressure foot to make ruffles, a significant decorative element in modern dress and one well-integrated into the fashion cycle (cf. Life 1967, 87). Piping, binding, French seams, and pinking were among other techniques on offer. In due course, such items were to disappear from sewing manuals published in China, but for the time being they were being integrated into the material fabric of life in the New China.

At the same time, Wang Guizhang was apparently well aware of what was required for and by New China, and so too were the advertisers who bought space in her book. 
Serge, a technically advanced and fashionably foreign-sounding fabric, might, like ruffles, sound out of place in the New Chinese wardrobe, but the advertisement made it clear that such was not the case. It could be used to make a Western suit, or a Western-style skirt and jacket, but it was equally appropriate for the working man's dungarees, the bureaucrat's Sun Yat-sen suit, the sailor's pants, and the schoolboy's uniform. This pure wool material, proclaimed the ad, was suitable for clothing the masses. The text was nicely calibrated to align the mission of the school with the mission of the State: "Production in our country at the present time has already became a most important and glorious matter. No matter whether male or female, young or old, knowledgeable or ignorant, rich or poor, the responsibility and duty to produce is the same" (Wang Guizhang 1950, 1).

This combination of New China ideology and pre-1949 commercial culture is visible in quite a different product: a sewing machine user's manual written by Comrade Liu Huishan, a worker in the Tianjin Leather Products Factory. According to the preface, Comrade Liu wrote the booklet on the basis of his own experience, and it was the more valuable for being a rare example of something written by a worker, using everyday language instead of technical vocabulary. It owed something, too, to the inspiration of Soviet works, such as Equipment for Machine-Made Shoes. Comrade Liu begins his exposition with a historical overview, describing the hand-operated (as opposed to treadle) machines of early times, and the great developments achieved by the working class in achieving a diversity of styles. Among them was the $34 \mathrm{~K}$, capable of operating at 750 rotations at minimum with a maximum stitch-length of 8 millimeters, useful for making military requirements, including boots, saddles, cannon covers, bullet holders, belts, and so on (Liu 1952, 27). The reader is taken into a world of nuts and bolts. Yet all this is packaged in a familiar way. The publisher was Commercial Press, one of the leading private publishers in China, and attention was paid to the aesthetics of book production. Different fonts with different levels of prominence are used for the names of the work, the series, the author, and the press (see figure 4). A well-executed drawing of a sewing machine advertises the contents of the book, against an art-deco background design in green stripes. The drawing shows a domestic sewing machine in front of a window. Trees can be seen through the window panes, and a curtain of printed cloth is shown with folds gently lifting, as if by a breeze. Under the zipper foot is a small embroidered doily. Here, then, is a certain idea of the sewing machine: it was associated with domestic use, luxury consumption, and female labor in the home.

It is not clear from Gerth's (2013) survey how far into the fifties and sixties advertisements continued to be in a modern, libidinous consumerist style, but the ads he shows are recognizably in a style from before 1949, and indeed mostly date from 1949. An advertisement such as that for the Butterfly sewing machine (see figure 3), generically similar to examples shown by Gerth for the refrigerator (1951) and skin cream (1949), was likely to have been a reprint or adaptation of an ad used in pre-Communist media. After 1949, technical and material resources for advertising were gradually depleted. This is plain from the afterlife of the image used for the Butterfly advertisement. The same image was used in a number of editions of manuals by Wang Guizhang between 1949 and 1951. In 1951, the figure of the woman at the sewing machine also appears in crude copy on the cover of a manual for Western tailoring by Beijing tailor $\mathrm{Fu}$ Yingfei 傅英飞 (see figure 5). Fu Yingfei may have felt the expectations of the socialist order more keenly than his Shanghai counterpart: he has adapted the figure to 


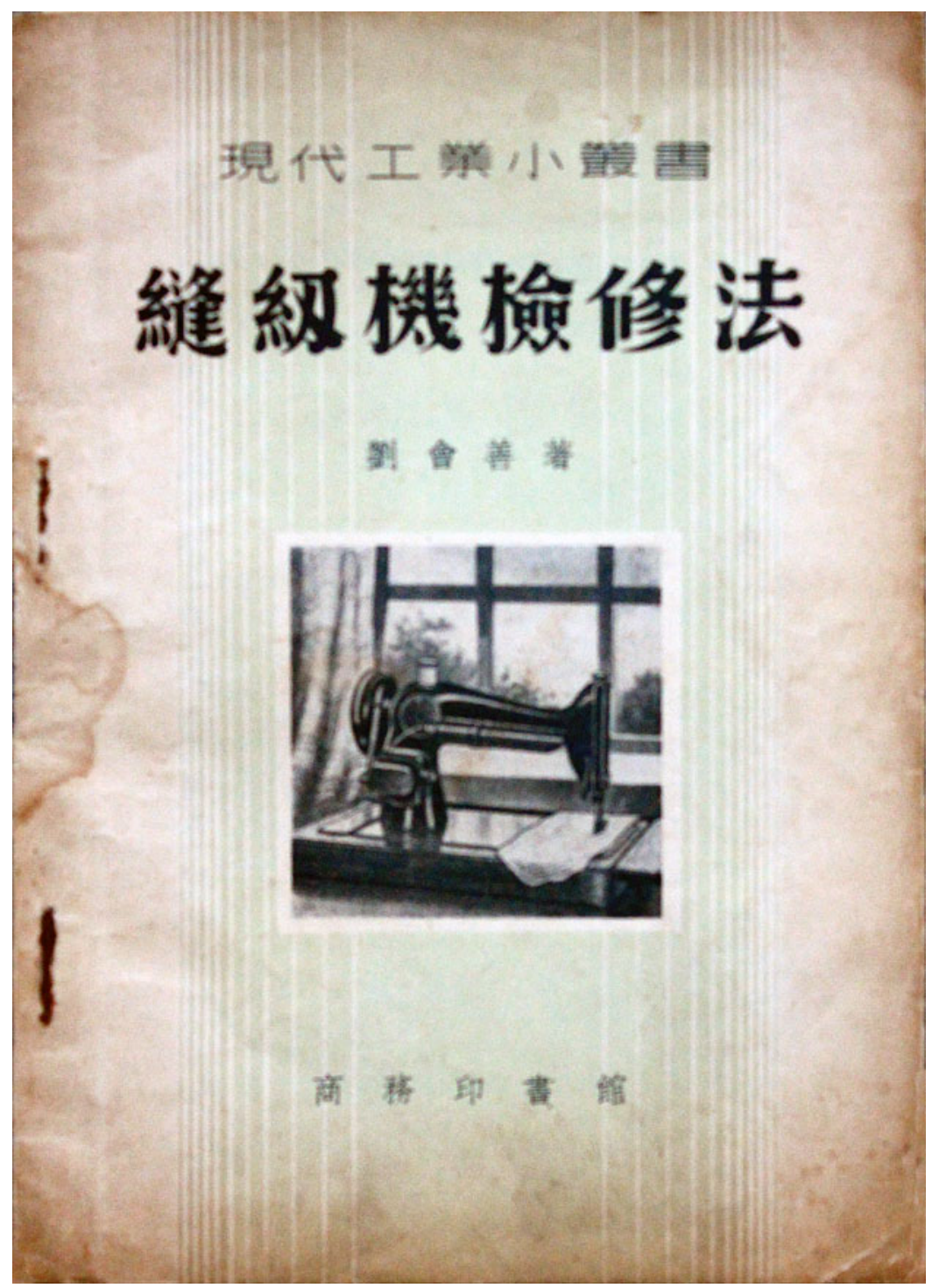

Figure 4. Front cover of a 1952 sewing machine repair manual (Liu 1952).

proletarian mold, in simple shirt, as opposed to qipao, and flat shoes rather than heels. But the original had another lease of life: in 1955, it was used for the front cover of a sewing machine user's manual for the Peony brand sewing machine, a state-private joint enterprise in Tianjin. By this time, the hairstyle of the sewer was clearly out of date: pattern books of the mid-fifties show the global trend of a short bob with a wave. The factory may have chosen such a cover, apparently designed in the first instance to advertise another brand in another city, because of a lack of skills in marketing and graphic design for this style of advertisement.

As we shall see, this is not because marketing, and more particularly brand identification, were matters of no moment in the command economy, but it is worth noting 


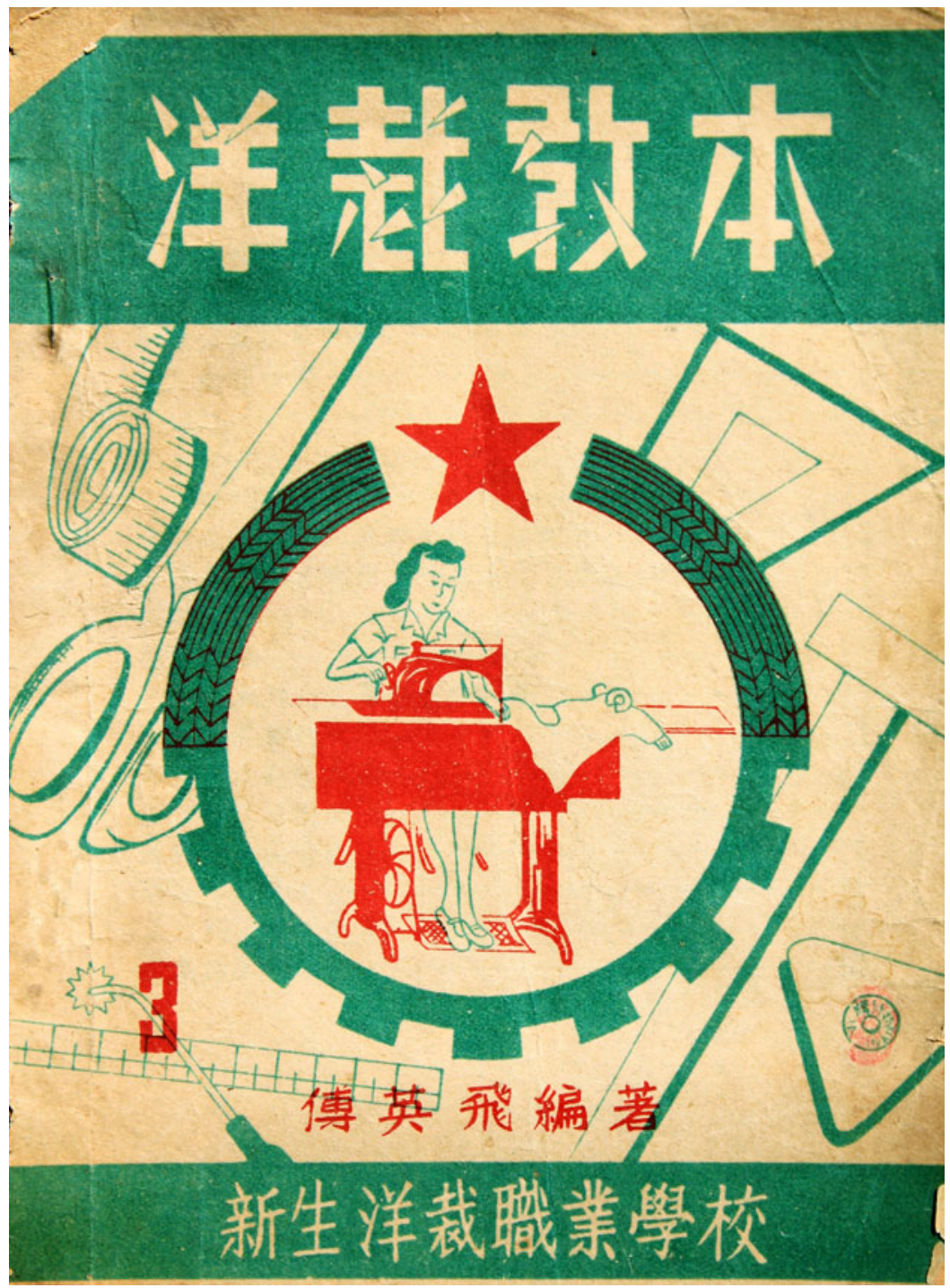

Figure 5. Front cover of a primer for how to sew "Western" (i.e., tailored) garments, prepared and printed by the teacher at the New Life Western tailoring vocational school in Xidan, Beijing. The Yah Chong advertisement appears to be the model, but the woman has changed clothes from qipao to plain shirt-style top, and from high heels to flat: altogether a more proletarian look ( $\mathrm{Fu} 1951)$.

the long-term trend away from the seductive advertising of bourgeois society. Wang Guizhang was a prolific producer of sewing and dressmaking manuals: between 1949 and 1959 she was responsible for at least half a dozen titles, some of which went through many printings. Advertisements are not carried in her later publications, but the diversity of dress styles presented in pattern books of 1956, in the midst of a national "dress pretty" (daban piaoliang 打扮漂亮) campaign (Finnane 2003), are consistent with contemporary 
world fashions and were designed to stimulate consumer appetites. This campaign marked one of the many turns in political temper in the first decade of the Communist era. In the late fifties, with the anti-rightist movement, the inauguration of the hukou system, and the launch of the Great Leap Forward, the socialist project in China assumed an increasingly grave aspect. The last reprint of any of Wang Guizhang's many "how to" books occurred in 1959, and her name disappears with it. She may have fallen victim to the anti-rightist movement. After the excesses of the Great Leap Forward, there was a period of economic readjustment nationwide, but the commercial culture of the transitional period, evident in publications of the early fifties, had been vitiated.

In its place was a new culture, a socialist culture, supported by appropriate state institutions. The China Advertising Company was established in 1956, with a Shanghai branch that subsequently shifted from state to municipal ownership. The nature of advertisements changed, and so did the discourse. As specialists in the area pointed out, there was a difference between capitalist and socialist advertising. The former was merely for profit. The latter was to serve the people, and was moreover "a reflection of production and construction." Nonetheless, advertising-primarily through newspapers and magazines-was built into the commodities supply system. The word itself disappeared during the Cultural Revolution, falling victim to associations with capitalism, but it was replaced by "commercial arts," which were institutionally embedded in foreign trade organs (Zhu 2009, 87-88).

In these years, the sewing machine industry slowly expanded. As articulated in a 1955 sewing machine user's manual: "In 1953 the fatherland's large scale economic construction began, the happiness and lives of the broad masses took another leap forward, women all actively rushed toward the high tide of production, the countryside was reforming its backward manual work, for these reasons the sewing machine business [was] developing in leaps and bounds day by day..." (Tianjinshi Dierwu Jindongzian 1955-56).

By 1964, there were thirty-one factories nationwide, in twenty-eight cities (see table 1). Most of these produced a standard domestic sewing machine, but two factories in Shanghai and one in Guangzhou produced a range of industrial machines (the $G$ series) as well as a diversity of domestic machines. Table 1 reveals something interesting about the development of the provincial factories. First, the name of the factory or state-owned company was a place-defined administrative name, signifying the complete identification of territorial administrative structure with industry management. In Shanghai, the old sewing machine companies mostly survived in name. In the capital and the provinces, however, the factories were mostly known just by place name: the Beijing factory, the Xi'an factory, the Fuzhou factory, and so on. Yet the responsible parties in each place were attuned to the importance of brand names. Although they were never able to compete with names such as Shanghai's Butterfly or Canton's Huanan, they gave their sewing machines meaningful and memorable names. Occasionally these were simply evocative older place names-Jinling in Nanjing, Bianjiang in Kaifeng. Sometimes very contemporary socialist names were used: Red Flag, Hero, Liberation, Leap Forward. A third option was the use of poetic, symbolic, or mythical birds and beasts: Flying Dove, Goose Brand, Swallow Brand, Black Dragon, Great Dragon, or (later) Panda (see figure 6). The most prosaic were plain topographical references, such as Min River for Fuzhou machines and Lu River for Xiamen machines, but on the whole there was a striking avoidance of simply using the place name as the brand name. 
Table 1. Sewing machine brand names, factory names, and sites of factories, 1964 (Wang Qianli 1964, 9-10).

\begin{tabular}{|c|c|c|c|}
\hline \multirow{2}{*}{$\frac{\text { Place }}{\text { Shanghai }}$} & \multirow{2}{*}{$\begin{array}{l}\text { Name of Factory } \\
\text { No. } 1^{*}\end{array}$} & \multicolumn{2}{|c|}{ Machine Brand } \\
\hline & & Feiren 飞人 & Flying Man \\
\hline & Xiechang 协昌 & Wudi无敌/Hudie 蝴蝶 & Invincible/Butterfly \\
\hline & Huigong 惠公 & Biaozhun 标准 & Typical (Standard) \\
\hline & Yuandong 远东 & Mifeng 蜜蜂 & Bee \\
\hline Tianjin 天津 & Huabei 华北 & Huabei 华北 & North China \\
\hline Guangzhou 广州 & Huanan 华南 & Huanan 华南/Feige 飞鸽 & South China/Flying Dove \\
\hline Beijing 北京 & Beijing & Yanpai 燕牌 & Swallow \\
\hline Qingdao 青岛 & Lianhua 联华 & Yinglun 鹰轮 & Eagle Wheel \\
\hline Xiangtan 湘潭 & Xiangtan & Youyi 友谊 / Jinjian 金箭 & Friendship/Golden Arrow \\
\hline Changsha 长沙 & Lianyi 联谊 & Lianyi 联谊 & Connection \\
\hline Chongqing 重庆 & $\begin{array}{l}\text { Jianshe Jichuang } \\
\text { Chang 建设机床厂 }\end{array}$ & E’pai 鹅牌 & Goose \\
\hline Changzhi 长治 & Changzhi & Taihang 太行 & Great Firm \\
\hline Xian 西安 & Xian & Dunhuang 敦煌 & Dunhuang \\
\hline Harbin 哈尔滨 & Harbin & Heilong 黑龙 & Black Dragon \\
\hline Qiqihar 齐齐哈尔 & Qiqihar & Chang'e 嫦娥 & Luna \\
\hline Changchun 长春 & Changchun & Jiefang 解放 & Liberation \\
\hline Shenyang 沈阳 & Shenyang & Julong 巨龙 & Great Dragon \\
\hline Lüda 旅大 & Lüda & Yuejin 跃进 & Leap Ahead \\
\hline Nanjing 南京 & Nanjing & Jinling 金陵 & Jinling \\
\hline Zhenjiang 镇江 & Zhenjiang & Gonglun 工轮 & Industrial Wheel \\
\hline Suzhou 苏州 & Suzhou & Xingfu 幸福 & Fortunate \\
\hline Wuxi 无锡 & Wuxi & Taihu 太湖 & Great Lake \\
\hline Jingjiang 靖江 & Jingjiang & Yingxiong 英雄 & Hero \\
\hline Hangzhou 杭州 & Hangzhou & Xihu 西湖 & West Lake \\
\hline Ningbo 宁波 & Ningbo & Hongqi 红旗 & Red Flag \\
\hline Tongxiang 桐乡 & Tongxiang & Qunying 群英 & Massed \\
\hline Hankou 汉口 & Hankou & Daqiao 大桥 & Great Bridge \\
\hline
\end{tabular}


Table 1. (contd.)

\begin{tabular}{|c|c|c|c|}
\hline Place & Name of Factory & \multicolumn{2}{|c|}{ Machine Brand } \\
\hline Fuzhou 福州 & Fuzhou & Minjiang 闽江 & Min River \\
\hline Xiamen 厦门 & Xiamen & Haidi 海堤 / Lujiang 鹭江 & Sea Dyke/Lu River \\
\hline Wuhu 芜湖 & Wuhu & Huanqiu 环球 & Globe \\
\hline Kaifeng 开封 & Kaifeng & Bianjing 泣京 & Bian City \\
\hline
\end{tabular}

*Originally the Ruan Yaoji Sewing Machine Co. The name was changed in 1954. 


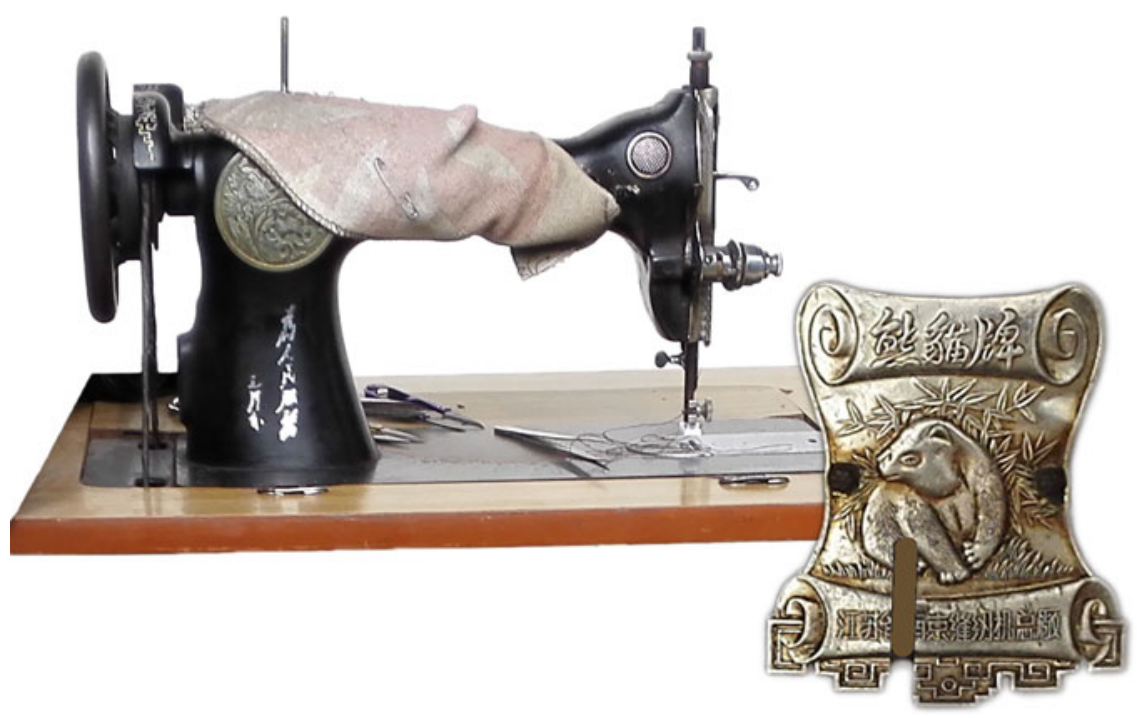

Figure 6. Panda brand sewing machine of the early 1970s. The panda logo (right) is displayed on the front of the machine. The machine is emblazoned on its rear side with words in the calligraphy of Mao Zedong (his name appended): "serve the people" (left). Photo by the author, Yangzhou, 2015.

Along with brand names came logos, or recognizable symbols for the machines. These can be seen in the making in sewing machine user and repair manuals produced in the middle of the 1950s, as socialist transformation brought existing companies under state control as so-called joint enterprises. An examination of the contents of the manual for the Tianjin Municipal Public-Private Joint Enterprise North China Sewing Machine Factory shows that it serves in part as an advertising brochure: customers are advised that they should negotiate purchase with the nearest department store, and that sole supply rights are vested in the Tianjin Department Store Purchase and Supply Station. Readers are informed that apart from the standard sewing machine for making clothes, the factory produces specialized machines for making shoe soles and paper bags, and that it also has a "Leap Forward Model Sewing Machine” (Yuejinxing fengrenji 跃进型缝 㧅机) - rather in advance of the Great Leap Forward of 1958. The four opening pages of the text proper, each with a photograph of a machine, all carry the logo in red, as though to impress the reader with the brand (Tianjinshi Dierwu Jindongzian 1955-56).

The logo is very similar to a number of others employed within the industry at this stage: a roundel with the upper part of the circle in a cog design and the lower of wheat. A variation of the design was used by $\mathrm{Fu}$ Yingfei for the front cover of his pattern book (see figure 5), but where Fu Yingfei has the figure of a machinist in the center of the roundel, the Tianjin sewing machine has the characters for 5.1 (i.e., May 1, International Workers' Day). Comparable are the logos for the Everlasting brand from Nanjing, with the word "Everlasting" in the middle; the Shanghai Municipal Sewing Industry logo, with a sewing machine in the center; and the Huanan, with something rather like Tiananmen in the middle. In the context of the socialist state, these logos were plainly unexceptionable. They were modeled on the national crest, designed by a Tsinghua University team in 
1949. That the factories desired recognition for these logos is plain: readers were alerted to them within the pages of the manuals. Equally obvious is the trend towards homogeneity. This was socialist brand identification, appropriate to a command economy.

At whom was such advertising directed? Barry Richman, in China in the mid-sixties, observed that advertising in China was more informative than persuasive, and directed more at wholesale and retail organizations than at the consumer (Richman 1969, 883). These characteristics were consistent with the limited choice available to consumers in any one place, and the dependence of enterprises on state-owned wholesalers and retailers to relieve them of their products. But exports provided an important incentive to maintain and develop communications about commodities. During the Cultural Revolution, when the word "advertising" fell victim to its associations with capitalism, it was replaced by the term "commercial arts," institutionally embedded in foreign trade organs (Zhu 2009, 87-88). Shanghai was the leader in this domain, producing industrial commercial designs not only for Shanghai products such as Feiyue but also for Flying Dove machines, which were a key export from Guangzhou. While advertising for mass consumption had ceased to be evident by the early seventies, it is observable that within the sewing machine industry there was an evolving sense of how to present technical information, probably again informed by foreign trade requirements. The coarsely printed sewing machine manuals of the 1950s were replaced by neat, small format booklets on good paper, which might well feature calls to "serve the people" but were for the most part cleaner and crisper than their predecessors in the fifties. They provided the model for user manuals through to the early nineties.

In the 1970s, the mishin phenomenon through which Japan had passed in the 1950s hit China. The introduction of coupons for sewing machine sales in 1972 indicates growing demand, or at least capacity to purchase, at that time. The coupons, like the machines, were made available through department stores: for the popular Feiyue machines they were initially issued in the proportion of one for every eighty people in Shanghai per year, with further numbers being issued to other administrative areas for mainly industrial purposes. According to former factory director Chen Guoyou 陈国有, the coupon cost 50 to 60 yuan, and the machine between 130 and 140 yuan, depending on type (Shanghai mingpai jiyi 2014). For a woman in a handicraft cooperative at the time, this might be half a year's pay. For rural women, who lived largely outside the cash economy, it was mostly beyond reach until the Reform Era. Under such circumstances, women in the towns of China saved up and queued for their machines. "The sewing machine in our home is not much younger than I am," writes Jiaoyue 媓月, born in Henan circa 1976. Her father had vowed that he would buy one for her mother when they had saved enough money, to save her spending every night sewing clothes and shoes. He bought a Huanan machine, and she made a cover to keep it from being soiled or damaged. Years later Jiaoyue woke with a start one night, with the “da-da” (哒哒) sound of the machine echoing in her ears (Jiaoyue 2012). For her cohort, "da-da" is no doubt part of a collective memory.

In these years, China first challenged and then surpassed Japan in units of sewing machines produced per annum. By 1984, an estimated 9,350,000 machines were being produced annually, an increasing number for export (Guojia tongju 1985, 153-55). At the same time, the gap between the two countries in standards of design and industry innovation made the limits of forced industrialization in the early decades of the PRC 
evident. A user's guide to sewing machines published in 1983 shows pictures of sewing machines ensconced in homes with television sets and pictures on the wall, and flowers in vases, evoking the modest prosperity that was emerging as a legitimate aim in Reform Era China (Huang 1983). The instructions on transport and assembly, however, show the primitive state of the infrastructure, comparable to the situation in New York a century earlier, where out-workers in the garment industry had to "hire a pushcart at a quarter, get the machine into the pushcart, trundle the load up to [the destination point], drag the machine up three or four flights of stairs, put it together, oil it, clean it, [and] supply all sorts of gadgets and tools, including needles" (Green 1997, 37).

A sense of picking up the threads dropped in the 1950s is well conveyed by the case of Zhang Bingcheng 张秉诚, author of a 1953 manual on sewing machine use. The quality of this early publication is unusually good for the period. Produced in small hardback format, like a prayer-book, it bears the title and an image of a sewing machine embossed in gold on the front cover and the spine. Its 206 pages include a chapter index, with title and subtitle, and an index of important points, with sixty-four entries. The text is in question-and-answer form. The technical drawings are detailed, and an illustrated appendix of parts is included. The machine stands shown in the appendix often show the Singer brand name, which had yet to become unmentionable. The author had set up a little sewing school in 1949, and in the preface described himself as "boldly" producing the book as a resource for teaching and work (Zhang 1953). Zhang Bingcheng fell victim to the Cultural Revolution, but in the Reform Era set about rebuilding his 1950s enterprise, founding a second sewing school in 1981, a third in 1998, and subsequently a small factory, with turnover in 2009 of up to 300,000 renminbi (Beijing chengren jiaoyu 1984, 27; Bejingshi 2010; cf. Schneider 2011, 202). Such energy and enterprise, allowed lease at an earlier stage, would surely have produced a mishin phenomenon in China rather sooner than was the case.

By the 1990s, China had become the world's major producer and exporter of sewing machines, emulating Japan's earlier achievements occasionally with Japanese help, via joint-enterprise arrangements. In 1999, with the first mass export of Feiyue machines to Japan, "the long sustained one-way trade in Japanese sewing machine imports was concluded" (Xu 2002, 215). But like Japan, China was moving on from the era of a machine in every dowry. Mass production meant that ready-to-wear clothing was fast becoming cheaper than homemade clothing could possibly be, and family sewing machines in increasing numbers were left to gather dust.

\section{Conclusion}

The sewing machine has deservedly attracted attention from historians. It stood at the heart of innovative and globally influential practices in manufacture and distribution in the United States. These practices included formation of combinations to manage patents and the mass deployment of credit purchase to allow a sewing machine into every home (Friedman 2009; Hounshell 1984). It transformed both commercial and home-based sewing, allowing the mass production of clothing in unprecedented quantities with consequences apparent in the fantastic scale of textile and clothing waste (Y. Wang 2006). Within the home, it became the focus of economic, social, aesthetic, and emotional concerns. It was a piece of domestic furniture and at the same time one of 
the very few machines to which women in a large number of societies were exposed as a matter of course, and on which they developed skills of not only sewing but also machine maintenance. For these various reasons, the history of the industry in different national contexts has much to reveal about differences and similarities between working environments, material cultures, gender relations, and economic and social change.

Research on the sewing machine in non-Western societies has been undertaken in a variety of national contexts (D. Arnold 2013; Finnane 2008; Kupferschmidt 2004), but Gordon (2012) is the first to have written about it at length. His point of departure was provided by a statistical report on Japanese households in the early fifties, which showed that married women daily spent more than two hours sewing. From a Chinese perspective, this figure is unsurprising. More hours again would have been spent per day by many women in China seeking to clothe their families. Asked about the family sewing machine in 2014, a native of Anhui now living in the West replied that his mother never had one. She had a spinning wheel. In that household, the women spun, wove, and sewed the clothes up to the time he left home, in the early eighties. His mother had no time to make his shoes: his sister made them, two pairs a year. He walked barefoot to school in the summer so as not to wear them out. An exact contemporary from Shanghai replied to the same question that he had grown up to the sound of the sewing machine. His family, former bankers, was forced to buy one after losing its servants. ${ }^{3}$ In Japan, people were less subject than were Chinese to the winds of political fortune in the fifties and sixties, but there can be little doubt that in the first decade and a half of the postwar era, women were making the clothes worn by the family. The emphasis on children's clothing in pattern books is consistent with this conclusion. It was only in the 1960s, as Gordon (2012, 207-8) shows, that "bridal-track" students came to dominate the ranks of students in sewing schools, and it was in that same decade, as he further notes (213), that the family sewing machine ceased to be in constant use.

A remarkable feature of the sewing machine's history is its appearance in and disappearance from the home in advanced economies. In Western countries, the sewing machine enjoyed pride of place among home appliances for around a century. In Japan and China, its reign was much shorter-about two decades in Japan (Gordon 2012, 154), and probably the same in China. In this respect, the sewing machine was different from some other appliances in modern homes: refrigerators; televisions; radios; or even gramophones, which have direct descendants in the form of sound systems. While the technology has by no means been superseded, the sewing machine as a household item has been rendered redundant by the altered circumstances of clothing production. Its limitations as an index to the consumer character of a society seem clear: surely this has been a tool of production as much as an item of consumption. In the Japanese context, its omission not only from the list of luxury items identified by Dore (1958; noted above) but also from the cornucopia of goods in a 1959 cartoon by Nasu Ryōsuke 那须良輔 (Gordon 2012, 183) prompts the question of how prominent advertisements were for sewing machines in any one period, relative to advertisements for other goods.

The manufacture and supply of sewing machines in both Japan and China took place in international contexts that variously enabled and constrained the industry's

\footnotetext{
${ }^{3}$ Personal communication with the author, Melbourne, August 29, 2013.
} 
development. In the case of Japan, the dramatic reduction of the China market in the 1950s meant a turn towards Southeast Asia for export destinations. In the case of China, protection from Japanese imports allowed breathing room for local industry. In both China and Japan, the legacies of empire are observable, inviting consideration of regional reservoirs of knowledge about Asia and its markets, including familiarity with routes, understanding of local cultures, and interpersonal connections.

There was some resentment in postwar Japan about the loss of empire, which "meant that she was deprived of major sources" for survival and was forced to depend simply on those available "in the narrow territory left to her" (Oriental Economist 1949, 1). Support for the sewing machine industry by the Ministry of International Trade and Industry in the 1950s is difficult to separate from this sentiment. On the Chinese side, the Nagasaki Flag Incident of 1958 led to a suspension of bilateral trade and a multifaceted international kerfuffle involving Taiwan and Southeast Asia, during which Japan's war record in Southeast Asia was aired (Hsiao 1977, 41-50). Overt popular criticism of Japan was by and large kept under control in mainland China during the Mao years but bubbled to the surface in the 1980s as a flood of Japanese imports led to charges of a second Japanese invasion — an "economic invasion."

Such historical references and perspectives coexisted with the tensions inherent in the Cold War world order. In the 1950s, these tensions were often marked. Yet this was a decade close to what preceded it: the war of the immediate past combined with the intensity of the present struggle to produce common elements in what Charles Maier has called the "psychosocial order" of the postwar decades. Maier identifies these: "a capacity for deferred gratification"; an "extraordinary public cohesion" around the rebuilding of industry and urban centers; "commitment to reconstituting traditional family and gender roles"; and "an unavowed determination to repress the memory of wartime violence and occupation, complicity, and even betrayal” (Maier 2010, 49). Maier was writing of the world at large. To different degrees, and taking into account the structural effects of the Communist program to liberate women, his conclusions are supported by the political mood and the economic program in both China and Japan. The figure of the housewife at her sewing machine in postwar Japan embodies this psychosocial order; but she had much in common with the socialist wife and mother in 1950s China (Evans 1997, 122, 133; Freeman 2011, 128-29).

\section{Acknowledgments}

Research for this article was supported by a grant from the Australian Research Council. I thank Bick-har Yeung, Lo-pei Neale, and Wei Ying of Baillieu Library, University of Melbourne, for help with resources for the research. Thanks are due also to Dr. Anne Peirson-Smith, CUHK, for inviting me to present a keynote address at the conference "Fashion in Faction: Style Stories and Transglobal Narratives," City University of Hong Kong, June 12-14, 2014. That address provided the foundations of this article.

\section{List of References}

Arnold, DAVID. 2013. Everyday Technology: Machines and the Making of India's Modernity. Chicago: University of Chicago Press. 
Arnold, Julean Herbert. 1919. Commercial Handbook of China. Vol. 1. Washington, D.C.: U.S. Government Printing Office.

BEIJING CHENGREN JIAOYU 北京成人教育 [BeIjING Adult EdUCATION]. 1984. “Ke zunjing de renmen congshi jiaoyu gongzuo sanshi niean de chenren jiaoyu gongzuozhe xuanjie - er" 可尊敬的人们 从事教育工作三十年的成人教育工作者选介(二) [People to look up to: Introducing a few adult education workers who have been engaged in educational work for thirty years, part 2]. 8:27-28.

“Beijingshi Xichengqu Dasheng Fuzhuang Fengren Xuexiao Xiaoban Gongchang” 北 京市西城区大生服装缝㧅学校校办工厂 [DASheng Garment Sewing School Factory, BeIjING City West]. 2010. www.114gb.com/gongsi/company_li/company_li_180855. html (accessed January 22, 2014).

Bodnár, Judit. 2001. Fin de Millénaire Budapest: Metamorphoses of Urban Life. Minneapolis: University of Minnesota Press.

Bonney, Catherine V. R. 1875. A Legacy of Historical Gleanings. 2 vols. Albany, N.Y.: J. Munsell.

Booker, M. Keith, and Dubravka Juraga. 2002. Socialist Cultures East and West: A PostCold War Reassessment. Westport, Conn.: Praeger.

Buckhardt [V. R. Burkhardt]. 2013. Chinese Creeds and Customs. London: Routledge.

Cheng Naishan 程乃珊 and He Youzhi 贺友直. 2005. Shanghai Fashion. Shanghai: Shanghai cishu chubanshe.

Coffin, Judith R. 1996. The Politics of Women's Work: The Paris Garment Trades, 1750-1915. Princeton, N.J.: Princeton University Press.

“Dangdai Zhongguo” Congshu Bianjibu 《当代中国》丛书编辑部编辑, ed., 1985-86. Dangdai Zhongguo qinggongye 当代中国轻工业 [Light industry in contemporary China]. Beijing: Zhongguo shehui kexue chubanshe: Xinhua shudian.

Dore, Ronald PhiLip. 1958. City Life in Japan: A Study of a Tokyo Ward. Berkeley: University of California Press.

Dower, John W. 1998. "The Useful War." In Showa Japan: Political, Economic and Social History, 1926-1989, Vol II: 1941-1952, ed. Stephen S. Large, 62-79. London: Routledge.

Dung KaI-Cheung. 2005. Tiangong kaiwu, xuxu ruzhen: Ershengbu xiaoshuo 天工開物, 栩 栩如真: 二聲部小説 [The exploitation of the works of nature, Xuxu and Ruzhen: A novel in two registers]. Hong Kong: Maitian chuban.

Evans, Harriet. 1997. Women and Sexuality in China: Female Sexuality and Gender since 1949. London: Bloomsbury Academic.

Finnane, Antonia. 2003. "Yu Feng and the 1950s Dress Reform Campaign: Global Hegemony and Local Agency in the Art of Fashion." In Voices amid Silence: Women and Modern Chinese Culture (II): 1600-1950, ed. Yu Chien Ming, 235-68. Taipei: Academia Sinicia.

—. 2008. Changing Clothes in China: Fashion, History, Nation. New York: Columbia University Press.

—. 2011. "Tailors in 1950s Beijing: Private Enterprise, Career Trajectories, and Historical Turning Points in the Early PRC." Frontiers of History 6(1):117-37.

FitzGerald, John. 1997. "Warlords, Bullies, and State Building in Nationalist China: The Guangdong Cooperative Movement, 1932-1936." Modern China 23(4):420-58.

Freeman, Caren. 2011. Making and Faking Kinship: Marriage and Labor Migration between China and South Korea. Ithaca, N.Y.: Cornell University Press.

Friedman, Walter A. 2009. Birth of a Salesman: The Transformation of Selling in America. Cambridge, Mass.: Harvard University Press. 
FU YINGFEI 傅英飞. 1951. Yangcai jiaoben 洋裁教本 [Primer in Western tailoring]. Beijing: Beijing xinsheng zhiye xuexiao.

— 1954. Xinfa jiancai: Fengren jiaoben 新法剪裁: 縫糿教本 [Tailoring in the new manner: Sewing primer]. Beijing: Beijing xinsheng zhiye xuexiao.

Galbraith, J. K. 1974. Economics and the Public Purpose. London: Andre Deutsch.

Garon, Sheldon. 1998. Molding Japanese Minds: The State in Everyday Life. Princeton, N.J.: Princeton University Press.

Garon, Sheldon, and Patricia L. McLachlan. 2006. "Introduction.” In The Ambivalent Consumer: Questioning Consumption in East Asia and the West, eds. Sheldon Garon and Patricia L. McLachlan, 1-16. Ithaca, N.Y.: Cornell University Press.

Gerth, KarL. 2013. "Compromising with Consumerism in Socialist China: Transnational Flows and Internal Tensions in 'Socialist Advertising." Past and Present 218(8): 203-32.

Gibney, Frank, ed. 2007. Sensō: The Japanese Remember the Pacific War: Letters to the Editor of Asahi Shimbun. Armonk, N.Y.: M.E. Sharpe.

Gordon, Andrew. 2012. Fabricating Consumers: The Sewing Machine in Modern Japan. Berkeley: University of California Press.

Green, Nancy L. 1997. A Century of Industry and Immigrants in Paris and New York. Durham, N.C.: Duke University Press.

Guojia Tonguu 国家统局 [State Statistical Bureau], ed. 1985. Zhongguo gongye jingji tongji 中国工业经济统计 [Statistics for China's industry and economy]. Beijing: Zhongguotongji chubanshe.

Gutzlaff, Karl Friedrich August. 1838. China Opened: Or, a Display of the Topography, History, Customs, Manners, Arts, Manufactures, Commerce, Literature, Religion, Jurisprudence, Etc., of the Chinese Empire. 2 vols. London: Smith Elder and Co.

Hale, Mrs. S. J., and L. A. Godey, eds. 1867. Godey's Lady's Book for 186774.

HE Mu 禾木. 2013. “Shouyao fengrenji” 手摇缝㧅机 [A hand-operated sewing machine]. Xinshangbao 新商报 [New business]. roll.sohu.com/20130707/n380900266.shtml (accessed March 30, 2014).

Hershatter, Gail. 2011. The Gender of Memory: Rural Women and China's Collective Past. Berkeley: University of California Press.

Horioka, Charles Yuji. 1993. “Consuming and Saving." In Postwar Japan as History, ed. Andrew Gordon, 259-92. Berkeley: University of California Press.

Hounshell, David A. 1984. From the American System to Mass Production, 1800-1932: The Development of Manufacturing Technology in the United States. Baltimore: Johns Hopkins University Press.

Hsiao, Gene T. 1977. The Foreign Trade of China: Policy, Law, and Practice. Berkeley: University of California Press.

Huanan Fengrenji Zhizaochang Changshi Bianxie Xiaozu. 1959. Huanan fengrenji zhizaochang changshi 华南缝㧅机制造厂厂史 [History of the Huanan Sewing Machine Factory]. Guangzhou: Guangzhou wenhua chubanshe.

Huang Shuomin 黄硕民. 1983. Zenyang yonghao fengrenji 怎样用好缝㧅机 [How to use a sewing machine properly]. Nanjing: Jiangsu kexue jishu chubanshe.

Igarashi, Yoshikuni. 2000. Bodies of Memory: Narratives of War in Postwar Japanese Culture, 1945-1970. Princeton, N.J.: Princeton University Press.

Iriye, Akira. 1992. China and Japan in the Global Setting. Cambridge, Mass.: Harvard University Press. 
Ji XUeYuAn 季学源 and Chen WANFEng 陈万丰, eds. 2003. Hongbang fuzhuangshi 红帮服装 史 [History of Red Group fashions]. Ningbo: Ningbo chubanshe.

JiAOYUE 晈月. 2012. “Fengrenji de dada sheng” 缝㧅机的哒哒声 [The tat-a-tat sound of the sewing machine]. Zhengzhou jiaoyu 郑州教育 [Zhengzhou education]. http://blog. zzedu.net.cn/jiaoyue/article_5DB4B192-AE74-44.html (accessed March 30, 2014).

Khoo, Salma Nasution. 2006. More Than Merchants: A History of the German-Speaking Community in Penang: 1800s-1940s. Penang: Areca Books.

Kirby, William C. 2004. "The Chinese Party State under Dictatorship and Democracy on the Mainland and on Taiwan." In Realms of Freedom in Modern China, ed. William C. Kirby, 113-38. Stanford, Calif.: Stanford University Press.

Конама, Нirohisa. 2007. Industrial Development in Post-War Japan. New York: Routledge.

Kupferschmidt, Uri M. 2004. "The Social History of the Sewing Machine in the Middle East." Die Welt des Islams, n.s., 44(2):195-213.

LIFE. 1967. "The Ruffle: A Swoon Song for Femininity Returns.” December 15, 87-89.

Lin ZhengbaO 林正苞. 1954. Caijian zhinan 裁剪指南 [Guide to tailoring]. Shanghai: Meilin caijian fengxiu zhuanxisuo.

LiU Huishan 刘会善. 1952. Fengrenji jianxiufa 缝㧅机检修法 [Sewing machine examination and repairs]. Shanghai: Shangwu yinshugua.

Maier, Charles. 2010. "The World Economy and the Cold War in the Middle of the Twentieth Century." In The Cambridge History of the Cold War, eds. Melvyn P. Leffler and Odd Arne Westad, 44-66. Cambridge: Cambridge University Press.

Marks, Robert. 2007. The Origins of the Modern World: Fate and Fortune in the Rise of the West. Lanham, Md.: Rowman \& Littlefield.

NA, Hye-Sŏк. 2010. "Kyŏnghŭi." In Questioning Minds: Short Stories by Modern Korean Women Writers, trans. Yung-Hee Kim, 24-54. Honolulu: University of Hawaii i Press.

Nishitani, KeIj. 1990. The Self-Overcoming of Nihilism. Translated by Graham Parkes with Setsuko Ahara. Albany: SUNY Press.

O'Bryan, Scott. 2009. The Growth Idea: Purpose and Prosperity in Post-War Japan. Honolulu: University of Hawai i Press.

Oriental Economist. 1949. Japan's Export Industries. Tokyo: Oriental Economist.

Pakenham, Compton. 1953. "Life and Love Today Inside Red China." News (Adelaide), July $24,21$.

Partner, Simon. 1999. Assembled in Japan: Electrical Goods and the Making of the Japanese Consumer. Berkeley: University of California Press.

Pence, Katherine. 2006. "Shopping for an 'Economic Miracle': Gendered Politics of Consumer Citizenship in Divided Germany." In The Expert Consumer: Associations and Professionals in Consumer Society, eds. Alain Chatriot, Marie-Emanuelle Chessel, and Matthew Hilton, 105-20. Aldershott, England: Ashgate.

People's China. 1953. Text of the Sino-Japanese Trade Agreement. 22, Supplement.

Perry, Elizabeth. 2012. Anyuan Mining: China's Revolutionary Traditions. Berkeley: University of California Press.

Qian Chuancang 钱传仓. 2003. Yangzhou minsu 扬州民俗 [Popular customs in Yangzhou]. Yangzhou: Fangzhi chubanshe.

ReId, Susan E. 2011. "Happy Housewarming!: Moving into Khrushchev Era Apartments." In Petrified Utopia: Happiness Soviet Style, eds. Marina Balina and Yevgeny Dobrenko, 133-60. New York: Anthem.

Richman, Barry. 1969. Industrial Society in Communist China: A Firsthand Study of Chinese Economic Development and Management, with Significant Comparisons 
with Industry in India, the U.S.S.R., Japan, and the United States. New York: Random House.

Schneider, Helen M. 2011. Keeping the Nation's House: Domestic Management and the Making of Modern China. Vancouver: UBC Press.

Sechiyama, Kaku. 2013. Patriarchy in East Asia: A Comparative Sociology of Gender. Translated by James Smith. Leiden: Brill.

SHANGHAI DIFANGZHI DIQIJIE: FENGRENJI 上海地方志——第七节㖓㧅 机 [SHANGHAI LOCAL GAZetTeEr, SEction 7: Sewing machines]. 2011. 360doc. http://www.360doc.com/ content/11/1007/15/1147381_154057715.shtml (accessed January 22, 2014).

SHANGHAI MINGPAI JIYI 上海名牌记忆 [RECOLLECTIONS OF SHANGHAI's FAMOUS BRANDS]. 2014. Baidu. http:/wenku.baidu.com/view/cb786f3a31126edb6fla107d.html (accessed October 1, 2014).

SHENGJIA GONGSI JIA MUBIAO 胜家公司价目标 [SingER SEWING MACHINES PRICE CATAlOG]. n.d. Incomplete; publication details missing, but probably from the 1930s. Special Collections, Baillieu Library, University of Melbourne.

Shiraishi, Takashi, and Caroline Sy Hau. 2010. "Only Yesterday: China, Japan, and the Transformation of East Asia." In The Cold War in Asia: The Battle for Hearts and Minds, eds. Yangwen Zheng, Hong Liu, and Michael Szonyi, 25-58. Leiden: Brill.

SMA (Shanghai Municipal Archives). 1954. "Shanghaishi junshi guanzhi weiyuanhui maoyichu disan junshi guanzhi zhuanyuan banshichu guanyu Meishang Shengjia fengrenjiqi gongsi jieshu qingkuang jizaizaiwenti de baogao”上海市军事管制委员会 贸易处第三军事管制专员办事处关于美商胜家缝㧅机器公司结束情况及现在问题的报告

[Report on the winding up and present problems of the American business Singer, from the No. 3 Military Control Bureau Assistant Director's Office, No. 3 Military Control Bureau in the Trade Sector, Shanghai Municipal Committee of the Military Control Commission]. March 2. B128-2-1217-247.

—. 1963. Zhonggong Shanghaishiwguoying Shanghai Dijiu Mianfangzhichang gongren xiaofei hezuoshe de jiancha zongjie baogao 中共上海市委政策研究室关于 国 营上海第九棉纺织厂工人消费合作的检查总结报告 [Summary report of the Policy Research Office of the Shanghai Municipal Committee of the Chinese Communist Party on the enquiry into the consumer cooperative of the workers of State-Owned Enterprise No. 9 Cotton Textiles Factory]. A4-1-30-150.

Song, Shaopeng. 2007. "The State Discourse on Housewives and Housework in the 1950s in China." In Rethinking China in the 1950s, ed. Mechtilde Leutner, 49-63. Berlin: LIT Verlag.

Sun Po 孙颇. 1951. Fengren shouce 裁缝手册 [Sewing manual]. Tianjin: Minde zhiye buxi xuexiao.

TACHI, Ryūichiro. 1966. "Fiscal and Monetary Policy.” Translated by Robert S. Ozaki. In Postwar Economic Growth in Japan, ed. Ryotaro Komiya, 11-31. Berkeley: University of California Press.

TAN JINTU 谭金土, contributor. 2004. “Zaoqi fengrenji zai Zhongguo” 早期缝㧅机在中国 [Early-era sewing machines in China]. In Lao zhaopian 老照片 [Old photos], ed. Shandong huabao chubanshe “lao zhaopian” bianjibu 山东画报出版社 “老照片” 编辑 部 37, 150-53. Jinan: Shangdong huabao chubanshe.

TANG DA 唐达. 1953. Fengrenji xuexifa 缝㧅机学习法 [Learning machine sewing]. Shanghai: Shanghai xinkexue chubanshe.

Tianjinshi Dierwu Jinzongdian Hongqi Menshibu Zhuangpei 天津市第二五金總店红旗門市 部裝配. 1955-56. Fengrenji: Jianjie shiyongfa ji jijian tuyang: Mudan pai 缝㧅機: 簡介 
使用法及機件备樣: 牡丹牌 [Sewing machines: A simple guide with illustrations of parts for Peony Brand]. Tianjin: Tianjinshi dierwu jinzongdian.

Tsui, Elaine Yi-Lan. 1993. "Feminist View on Gender Relationship in Contemporary Taiwan." In Norms and the State in China, eds. Chun-chieh Huang and Erik Zürcher, 207-18. Leiden: Brill.

Uno, Kathleen. 1993. "Death of the 'Good Wife, Wise Mother??” In Postwar Japan as History, ed. Andrew Gordon, 293-321. Berkeley: University of California Press.

Vowinckel, Annette, Marcus M. Payk, and Thomas Lindenberger. 2012. Cold War Cultures: Perspectives on Eastern and Western European Societies. Oxford, N.Y.: Berghahn.

Wang, Gabe T. 2006. China and the Taiwan Issue: Impending War at Taiwan Strait. Lanham, Md.: University Press of America.

WANG GuIZHANG 王圭璋. 1950. Fengren nanzhen 缝㧅南针 [King Fair instructions: Sewing and stitching]. 2nd ed. Shanghai: Jinghua.

Wang Qianli 汪千里, ed. 1964. Fengrenji 缝㧅机 [Sewing machines]. Beijing: Zhongguo caijing jingji chubanshe.

Wang, Youjiang. 2006. Recycling in Textiles. Cambridge: Woodhead.

Whyte, Martin King. 1985. Urban Life in Contemporary China. Chicago: University of Chicago Press.

Wu, Yu-shan. 1994. Comparative Economic Transformations: Mainland China, Hungary, the Soviet Union, and Taiwan. Stanford, Calif.: Stanford University Press.

XIONG SAIZHEN 熊塞声. 1958. “Yijia fengrenji”一架缝㧅机 [The sewing machine]. Juben, November 27, 69-75.

Xu Weinua 徐卫华. 2002. “Weile Zhongguo de Feiyue—dangde 'shiliuda' daibiao, Feiyue jituan dongshichang Qiu Jibao de chuangye chuanqi”为了中国的飞跃一党的”十六 大”代表、飞跃集团董事长邱继宝的创业传奇 [Feiyue for China: The entrepreneurial story of Qiu Jibao, representative at 16th Party Congress and CEO of the Feiyue Group]. Zhongguo zuojia 11:191-244.

Yue Zhong 乐忠 and Xu LanhuA 徐兰花. 1958. “Bian xiaofeizhe wei shengchanzhe: Bian xiaofei chengzhen wei shengchan chengzhen”变消费者为生产者变消费城镇为生产城镇 [Changing consumers into producers: Changing consumer towns into producing towns]. Chuangzao 2:54-57.

ZHANG BingCHENG 张秉诚. 1953. Fengrenji shiyong shouce 缝㧅机实用手册 [Sewing machine user's handbook]. Beijing: Beijing wenhua xueshe.

Zheng Yuan. 2001. "The Status of Confucianism in Modern Chinese Education, 19011949: A Curricular Study." In Education, Culture and Identity in Twentieth-Century China, eds. Glen Peterson, Ruth Hayhoe, and Yongling Lu, 193-237. Ann Arbor: University of Michigan Press.

Zhu Hanguo 朱汉国 and Zhang TaiYuan 张太原. 2005. Dangdai Beijingshi jumin de xiaofei shenghuo fangshi (1956 nian - 1988 nian) 当代北京市居民的消费生活方式 1956 年 1986年 [The consumer lifestyles of residents of contemporary Beijing (19561988)]. Beijing: Beijing chubanshe.

Zhu SHuA 祝帅. 2009. “Xin Zhongguo qian sanshi nian guanggao yanjiu de geju jiqi jiben mianxiang - 1949-1979 nianjian Zhongguo de guanggao xueshu lunzhu de lishi yu fenxi” 新中国前三十年广告研究的格局及其基本面向 - 1949-1979 年间中国的广告学术论著 的历史于分析 [Research structure and basic approach to advertising in the first thirty years of the New China: History and analysis of academic work on advertising in China, 1949-1979]. Guanggao daguan - lilunban, August, 87-96. 